\title{
COMMENTS
}

\section{THE ETHICS OF MOVING TO DISQUALIFY OPPOSING COUNSEL FOR CONFLICT OF INTEREST}

A court, in exercise of its inherent powers of supervision, ${ }^{1}$ may disqualify counsel found to be in conflict of interest with respect to a case before the court. When opposing counsel is in a serious conflict of interest, it is clearly the duty of an attorney to move for disqualification. Some motions to disqualify opposing counsel, however, may be nothing more than tactical devices to delay the proceedings or to remove opposing counsel, not because of the purported conflict of interest, but because opposing counsel is dangerously competent. In such cases a motion to disqualify is surely at least prima facie unethical. This Comment will discuss criteria for distmguishing those situations in whicl a motion to disqualify opposing counsel for conflict of interest is ethically mandatory, ethically permissible, and ethically impermissible.

\section{The Law of Disqualification for Conflict of INTERest}

While it is beyond the scope of this Comment to discuss the details of the law of disqualification, ${ }^{2}$ it is necessary to sketch the general context in which the decision to move to disqualify opposing counsel is made. In analyzing a conflict of interest situation it is useful to ask what relations of counsel give rise to the conflict and who stands to be harmed by that conflict. The relations giving rise to conflicts of interest in disqualification cases imclude personal relations of the attorney, ${ }^{3}$ present representation of a potentially adverse party, ${ }^{4}$ and prior repre-

THE FOLLOWING CITATIONS WILL BE USED IN THIS COMMENT:

ABA Code of Professional Responslbility (1978) [hereinafter cited as Code; Disciplinary Rules and Ethical Considerations therem heremafter cited only by DR and EC numbers];

ABA Comm. on PROFEssional ETHICs, OpINIONs [hereinafter cited as OpINIONS].

1. In re Gopman, 531 F.2d 262, 266 (5th Cir. 1976); Estates Theatres, Inc. v. Columbia Pictures Indus., 345 F. Supp. 93, 95 n.1 (S.D.N.Y. 1972).

2. See generally Liebman, The Changing Law of Disgualification: The Role of Presumption and Policy, 73 Nw. U.L. Rev. 996 (1979).

3. See, e.g., Bachman v. Pertschuk, 437 F. Supp. 973 (D.D.C. 1977) (counsel also a member of plaintiff class). See also DR 5-101(A).

4. See, e.g., Cimema 5, Ltd. v. Cinerama, Inc., 528 F.2d 1384 (2d Cir. 1976). See also EC 514, -20; DR 5-105; H. DrinKER, LeGAL ETHICS 103-30 (1953). 
sentation of an adverse party. ${ }^{5}$ Parties who inay be injured by the conflict of interest imclude the present client of the attorney moving to disqualify opposing counsel, the present client of the attorney who is the target of the motion, ${ }^{6}$ and third parties. The law witl respect to disqualification varies depending on the conflict relation and the potentially liarmed party. This Comment will focus on those cases in which an attorney moves to disqualify opposing counsel because the opponent previously represented the inovant's client or has professional ties to attorneys who previously represented the movant's client. These cases are common among the reported disqualification cases, and the ethical problems this Comment discusses will be more definite in this restricted setting. The results of the discussion can be fairly easily extended to other conflict disqualification contexts.

\section{A. The Substantial Relationship Test.}

A court may disqualify counsel when the subject matter of a case bears a "substantial relationship" to a matter in which counsel previously advised or represented the presently adverse party.7 A "substantial relationship" should be understood as a relationship in whicl it is possible that the attorney obtained confidential information from the former client. ${ }^{8}$ This reading of the test may be inferred from the most frequently cited justification for disqualification under the substantial relationship test: protection of client confidences, which in turn preserves client trust in the attorney and furtlers free communication between client and attorney. 9 When the substantial relationship exists, the court will irrebuttably presume that the attorney received confidential information relevant to the present case. ${ }^{10}$ Evidence describing the

5. See, e.g., United States v. Bishop, 90 F.2d 65 (6th Cir. 1937). See generally Note, Attorney's Conflict of Interests: Representation of Interest Adverse to That of Former Client, 55 B.U. L. REv. 61 (1975); Annot., 52 A.L.R.2d 1243 (1957).

6. In these cases the requirements for disqualification will be high if the client, after full disclosure, cliooses to continue to be represented by the counsel who is the subject of the disqualification motion. Melamed v. ITT Continental Baking Co., 592 F.2d 290, 293 (6th Cir. 1979) (requiring "real and substantial harm").

7. This test was enunciated in T.C. Theatre Corp. v. Warner Bros. Pictures, 113 F. Supp. 265, 268 (S.D.N.Y. 1953).

8. Aronson, Conflict of Interest, 52 WaSh. L. REv. 807, 834 (1977).

9. See, e.g., First Wis. Mortgage Trust v. First Wis. Corp., 571 F.2d 390, 396 (7th Cir. 1978); United States v. Standard Oil Co., 136 F. Supp. 345, 355 (S.D.N.Y. 1955). Under DR 4-101(B),

[e]xcept when permitted under DR 4-101(C), a lawyer shall not knowingly: (1) Reveal a confidence or secret of his chient. (2) Use a confidence or secret of his chent to the disadvantage of the client. (3) Use a confidence or secret of his client for the advantage of himself or of a third person, unless the client consents after full disclosure.

10. Schloetter v. Railoc of Ind., Inc., 546 F.2d 706, 710 (7th Cir. 1976); Government of India v. Cook Indus., 422 F. Supp. 1057, 1060 (S.D.N.Y. 1976), affd, 569 F.2d 737 (2d Cir. 1978), and cases cited therein. 
former counsel's information will not be admitted."1

\section{B. Vicarious Disqualification.}

Disqualification is vicarious when a court disqualifies a lawyer because he or she was a nember of a firm that previously represented the adverse party or when a court disqualifies a firm because one of its members previously represented the adverse party. The Code of Professional Responsibility endorses the concept of vicarious disqualification in DR 5-105(D): "If a lawyer is required to decline employinent or to withdraw from employment under a Disciplinary Rule, no partner, or associate, or any other lawyer affiliated with him or his firm, may accept or continue such einployinent."12 The chief justification for this rule is that lawyers in the same firm have strong professional, pecuniary, and personal reasons for talking to each other about cases. ${ }^{13}$ These reasons are thought to be sufficient to extend the applicability of vicarious disqualification to attorneys sharmg office space ${ }^{14}$ and to student law clerks. ${ }^{15}$

In the view of the ABA Committee on Ethics and Professional Responsibility, DR 5-105 extends disqualification to the firm without imputing the attorney's knowledge to the firm. ${ }^{16}$ The courts, lowever, have generally followed the semmal 1955 case, Laskey Bros. of West Virginia, Inc. v. Warner Bros. Pictures, ${ }^{17}$ basing vicarious disqualification on an irrebuttable presumption of transfer of information froin the attorney to the firm of whicl he or she is then a meinber. If, however, a vicariously disqualified partner leaves the firm and joins another, the presumption is rebuttable, and his or ler new partners will not necessarily be disqualified. "[T]liey need show only that the vicariously disqualified partner's knowledge was imputed, not actual." 18

This second stage rebuttability of the imputation of confidential information lessens the rigors of the vicarious disqualification doctrine. Recent decisions have restricted the doctrine furtlier. Despite the unequivocal language of DR 5-105, the United States district court in Sil-

11. It is argued that permitting evidence on this question would defeat the purpose of preservation of confidences and trusts. Government of India v. Cook Indus., 422 F. Supp. at 1060.

12. DR 5-105(D). See also OpINIONS No. 342, at 1 (1975).

13. OpINIONS No. 342, at I n.2 (1975).

14. See OpINIONS No. 104, at 356-57 (1934).

15. See, e.g., American Roller Co. v. Budinger, 513 F.2d 982 (3d Cir. 1975). See also A.B.A. Comm. on Professional Ethics, INFormal. OpINIONS No. 1092 (1968); H. Drinker, supra note 4 , at 107.

16. OpINIONS No. 342 , at 8 n.25 (1975).

17. 224 F.2d 824 (2d Cir. 1955), cert. denied, 350 U.S. 932 (1956).

18. American Can Co. v. Citrus Feed Co., 436 F.2d 1125, 1129 (5th Cir. 1971). 
ver Chrysler Plymouth v. Chrysler Motors Corp. ${ }^{19}$ declined to disqualify an attorney wlio, as a young associate with another firm, liad played a minor role in the tainting litigation. The court rejected the Laskey doctrime of irrebuttably imputed knowledge within tle firm by refusing to impute to the lawyer his former colleagues' knowledge. "Tlie law inust reject defendants' suggestion that for purposes of disqualification, in an organization as large as Kelley Drye, every associate is charged with the knowledge of the confidences of every lawyer in the firm."20

In affirming Silver Chrysler, the Second Circuit einpliasized two reasons for limiting vicarious disqualification: tlie riglit to counsel of one's choice and the importance of retaining inobility for lawyers whose careers start in large firms. Concern for the right to choose counsel is a factor in nearly all decisions denying disqualification notions. "Motions to disqualify opposing counsel are disfavored. Disqualification has a serious and immediate adverse effect by denying the client his choice of counsel."21 Several authorities have recognized that the effect of rigorous vicarious disqualification on the riglit to clioice of counsel is particularly serious when the available choices are otherwise restricted, as they may be in a specialized legal field.22 Similar restricted supply problems nnay arise in isolated geographical areas for indigent clients ${ }^{23}$ and, in effect, for clients with long-established relationships with a particular counsel.

There also seeins to be increasmg judicial sensitivity to the career problems vicarious disqualification can cause for attorneys, especially attorneys who start their careers with large firms or with the governinent and becoine specialists. ${ }^{24}$ The Court of Claims, for example, lias expressed a desire to avoid vicarious disqualification rules that cause the government lawyer to "infect all the ineinbers of any firm he join[s] witl all his own personal disqualifications," so that lie or slie "take[s]

19. 370 F. Supp. 581 (E.D.N.Y. 1973), affd, 518 F.2d 751 (2d Cir. 1975).

20. $370 \mathrm{~F}$. Supp. at 587.

21. Society for Good Will to Retarded Children, Inc. v. Carey, 466 F. Supp. 722, 724 (E.D.N.Y. 1979); see Board of Educ. v. Nyquist, 590 F.2d 1241, 1246 (2d Cir. 1979).

22. United States v. Standard Oil Co., 136 F. Supp. 345, 363 (S.D.N.Y. 1955); see Emel Indus. v. Patentex, Inc., 478 F.2d 562, 574-75 (2d Cir. 1973) (disqualification allowed despite recognition of problems of access to counsel specializing in patent law). See also OpINions No. 342, at 4-5 (1975); Note, Disqualification of Attorneys for Representing Interests Adverse to Former Clients, 64 Y ALE L.J. 917 (1955).

23. See Aronson, supra note 8, at 856-57.

24. Compare Consolidated Theatres, Inc. v. Warner Bros. Circuit Management Corp., 216 F.2d 920 (2d Cir. 1954), with Silver Chrysler Plymouth v. Chrysler Motors Corp., 518 F.2d 751 (2d Cir. 1975). See generally Opinions No. 342, at 10-12 (1975); Note, The Second Circuit and Attorney Disqualification-Silver Chrysler Steers in a New Direction, 44 FordHaM L. Rev. 130 (1975).

The argument against vicarious disqualification premised on lawyer mobility is set forth in a frequently cited Yale Law Journal note, Note, supra note 22, at 928. 
on the status of a Typhoid Mary, and [is] reduced to sole practice under the most unfavorable conditions." 25

Some courts have also recognized that rigorous vicarious disquahfication can pose monumental problems for the day-to-day functioning of large firms. Simce such firms "represent the largest corporations with interests im all sectors of the economy, it is almost impossible to have an important client or its subsidiary avoid some kind of legal relationship witl another chent at some time."26 It is for just this reason, of course, that large firms are the targets of so many motions to disqualify for conflict of imterest. The district court in Silver Chrysler took the position that "[a]ntitrust implications in unduly restricting the work of the largest law firms' former associates are not insubstantial simce these firms have as clients corporations that control a major share of the American economy. Large law firms may not protect their clients by monopolizing young talent."27

These concerns have led to a moderation in the judicial view of vicarious disqualification.

[R]ecent prevailing legal precedent has rejected the harsh, hard-line approach of irrebuttably imputing confidential disclosures, actual or presumed, received by one meinber of a law firm to all meinbers of that law firm in favor of the more realistically equitable logic, attuned to conteinporary legal practices common to einerging law firms of substantial size. ${ }^{28}$

Rigorous vicarious disqualification based on literal interpretation of DR 5-105(D) will most probably continue to decline. When necessary the lawyer with the direct conflict of interest will be "screened" from the later case. ${ }^{29}$

25. Kesselhaut v. United States, 555 F.2d 791, 793 (Ct. Cl. 1977). The special problems of vicarious disqualification of former government lawyers have given rise to a lively debate as to whether DR 5-10S(D) is to be liberally applied to the former governments lawyer's new firm. See Note, Ethical Problems for the Law Firm of a Former Government Attorney: Firm or Individual Disqualification, 1977 DuKE L.J. 512; Commentary, The Disqualification Dilemma: DR 5-10S(D) of the Code of Professional Responsibility, 56 NEB. L. Rev. 692 (1977).

26. Silver Chrysler Plymouth, Inc. v. Clrysler Motors Corp., 370 F. Supp. 581, 588 (E.D.N.Y. 1973), affd, 518 F.2d 751 (2d Cir. 1975).

27. 370 F. Supp. at 591 (citations omitted).

28. City of Cleveland v. Cleveland Elec. Illuminating Co., 440 F. Supp. 193, 210 (N.D. Ohio), affd, 573 F.2d 1310 (6th Cir. 1977). A decision that runs counter to the prevailing trend, by asserting that the size of the firm is irrelevant, is Westimghouse Elec. Corp. v. Kerr-McGee Corp., 580 F.2d 1311, 1318 (7th Cir.), cert. denied, 439 U.S. 955 (1978). For a general discussion of the relation of firm size to disqualification, see Liebman, supra note 2, at 1017-18.

29. See Kesselhaut v. United States, 555 F.2d 791 (Ct. C1. 1977); OpINions No. 342, at 11 (1975). But see Armstrong v. McAlpin, 606 F.2d 28 (2d Cir. 1979) (rejecting the sufficiency of screening where government lawyer might be tempted to conduct case so as to enhance future private employment), rehearing en banc granted, No. 79-7042 (2d Cir. Dec. 12, 1979). The petition for an en banc rehearing of the Armstrong case was supported by an amicus curiae brief by former 


\section{The Appearance of Impropriety.}

The trend away from strict vicarious disqualification is parallel to, and in part the result of, a trend away from the strictest possible interpretation and apphication of the Nimth Canon of the Code: "A lawyer should avoid even the appearance of professional impropriety." After the adoption of the Code in $1969,{ }^{30}$ judicial decisions on disqualification frequently discussed the appearance of impropriety issue. ${ }^{31}$ The lack of confidence in the legal profession that followed Watergate undoubtedly spurred interest in Canon Nime. ${ }^{32}$

The appearance of impropriety is a consideration that worked im tandem with the "transmission of confidences" analysis in prior representation disqualification cases. It helped justify, for example, the irrebuttabihty of the presumption that confidences passed from chent to attorney. ${ }^{33}$ In addition, because of appearance of impropriety considerations, courts have ordered disqualification despite an origmal informed acquiescence in the choice of the opposing counsel. ${ }^{34}$

There can be no doubt that Canon Nine remams an important factor in disqualification cases, but recent decisions have shown a tendency to require more than a bare appearance of impropriety. Thus, one district court held that "[ $t]$ he possibility that an attorney's represen-

senior government lawyers. See Lawyers: Ease Conflicts Ruling, Nat'l L.J., Nov. 12, 1979, at 4, col. 4.

30. Code ii.

31. See Note, Ethical Considerations When an Attorney Opposes a Former Client: The Need for a Realistic Application of Canon Nine, 52 CHI.-KENT L. REv. 525, 530-38 (1975), and cases cited therein.

32. See id. at 537, and authorities cited therein.

33. See Liebman, supra note 2, at 1001 ; Note, supra note 22 , at $920-21$, and authorities cited therein.

34. W. E. Bassett Co. v. H. C. Cook Co., 201 F. Supp. 821 (D. Conn. 1961), affd per curiam, 302 F.2d 268 (2d Cir. 1962). See also Note, Unchanging Rules in Changing Times: The Cannons of Ethics and Intra-Firm Conflicts of Interest, 73 YALE L.J. 1058, 1062-63 (1964). The appearance of impropriety consideration has also given rise to some strong judicial language requiring disqualification: "[A]n attorney may be required to withdraw from a case where there exists even an appearance of a conflict of interest," Schloetter v. Railoc of Ind., Inc., 546 F.2d 706, 709 (7th Cir. 1976); "[I]n the disqualification situation, any donbt is to be resolved in favor of disqualification," Hull v. Celanese Corp., 513 F.2d 568, 571 (2d Cir. 1975). The court further noted

The preservation of public trust both in the scrupulous administration of justice and in the integrity of the bar is paramount. Recognizably important are [plaintiffs] right to counsel of her choice and the consideration of . . . judicial economy . . . . These considerations must yield, however, to considerations of ethics which run to the very integrity of our judicial process.

Id. at 572. The confiict of interest in this latter case was dramatic. Plaintiffs lawyer sought to represent as intervening plaintiff one of defendant's in-house lawyers, who had been active in the defense of the case before the court (involving sex discrimination). There was evidence of actual transmission of confidential information. Therefore the "appearance of impropriety" approach was adopted inore out of an abnndance of judicial caution than out of necessity. 
tation in a given case may give rise to an 'appearance of impropriety' is not enougli to disqualify. Specific facts must point to a marked danger that the perceived evil . . . will result." 35 Likewise, the Second Circuit lield that "when there is no claim that the trial will be tainted, appearance of impropriety is simply too slender a reed on which to rest a disqualification order except in the rarest cases." 36 The Silver Chrysler district court mamtained that hasty disqualification solely on the basis of appearance of impropriety charges will itself tend to undermine the confidence in the legal system that Canon Nine is intended to foster. ${ }^{37}$

It would be easy to overstate botll the "Watergate" trend towards increasing reliance on Canon Nime and the more recent trend in the other direction. ${ }^{38}$ There has undoubtedly been a greater change in language than in the way cases will be decided. It does seem, however, that courts are now doctrinally prepared to deny tactical disqualification motions that are based only on a speculative assertion of the appearance of impropriety.

\section{Conclusions on the Law of Disqualification.}

For purposes of a discussion of the ethics of moving to disqualify opposing counsel, a key question is low often a motion will result im a disqualification when there should have been none. It is clear that a technical Code violation will no longer invariably result in disqualification. ${ }^{39}$ Courts have become sensitive to the tactical abuse of notions to disqualify. As the Fifth Circuit has observed, "[i]nasmuch as attempts to disqualify opposing counsel are becoming increasingly frequent, we cannot perinit Canon 9 to be manipulated for strategic advantage on the account of an impropriety which exists only in the minds of imaginative lawyers." 40 In a dramatic recent developınent, a district court went so far as to require that moving attorneys pay lawyer's fees under

35. Society for Good Will to Retarded Children, lnc. v. Carey, 466 F. Supp. 722,724 (E.D.N.Y. 1979).

36. Board of Educ. v. Nyquist, 590 F.2d 1241, 1247 (2d Cir. 1979).

37. Silver Chrysler Plymouth, Inc. v. Chrysler Motors Corp., 370 F. Supp. 581, 589 (E.D.N.Y. 1973), affd, 518 F.2d 751 (2d Cir. 1975).

38. It has been suggested that Silver Chrysler, which expressed a concern to avoid an "excess of ethical fervor," 370 F. Supp. at 591, in disqualifying in terms of Canon Nine, stood in isolated opposition to the trend toward inore aggressive application of the Canon. Note, supra note 31, at 536-37. Froin the vantage point of 1979, it appears inore accurate to say that Silver Chrysler was the beginning of a continuing trend liniting the doctrine that a inere appearance of impropriety is sufficient to disqualify an attorney in a prior representation case.

39. Central Milk Producers Coop. v. Sentry Food Stores, Inc., 573 F.2d 988, 991 (8th Cir. 1978).

40. Woods v. Covington County Bank, 537 F.2d 804, 819 (5th Cir. 1976). See also OpINions No. 342, at 4-5 (1975). 
28 U.S.C. \& $1927(1976)^{41}$ when it found their disqualification motion to be "patently frivolous," and intended to "harass" and "delay." 42 Unjustified disqualifications will surely continue. Nevertheless, there is reason to beheve that their number will be held down by mcreasing judicial reluctance to disqualify when the conflict of interest is marginal and the movant's motivation is tactical.

\section{The Ethical Considerations}

The ethically difficult decision of whether or not to inove to disqualify opposing counsel arises when there is a very sinall probability of significant harm or a significant probability of a very small harm to one's client if opposing counsel is not disqualified. In these cases the movant has a small "expected utility" 43 gain in making the motion. Typically, the cost for the adverse party will be considerably greater im terms of choice of counsel and the necessity for repetition of at least soine of counsel's preparatory labors. ${ }^{44}$ The hard cases, then, are those in which the motion to disqualify is not totally frivolous, but the benefit it will yield by removing the conflict of imterest is sinall relative to the harm it inflicts upon the adverse party apart from the loss of any conflict of interest advantage. In short, the hard case is one in which, from a neutral viewpoint, there should be no disqualification but in which disqualification would modestly serve the interest of one's client.

\section{A. The Obligation to Move to Disqualify.}

One appealingly simple solution to the ethical problem is to say that one has a duty to inove to disqualify opposing counsel whenever there is a nontrivial possibility of a conflict of mterest. The existence of such a duty may arise from DR 1-103(A): "A lawyer possessing unprivileged knowledge of a violation of DR 1-102 shall report such knowledge to a tribunal or other authority einpowered to investigate or act upon such violation." 45 DR 1-102 is violated whenever there is a

41. 28 U.S.C. $\$ 1927$ (1976) provides: "Any attomey or other person admitted to conduct cases in any court of the United States or any Territory thereof who so nultiplies the proceedings in any case as to increase costs unreasonably and vexatiously inay be required by the court to satisfy personally such excess costs."

42. North Ain. Foreign Trading Corp. v. Zale Corp., 83 F.R.D. 293, 296 (S.D.N.Y. 1979).

43. Expected utility equals utility multipled by the probability of that utility's being realized.

44. Some or all of the disqualified attorney's work product may be judicially denied to the new counsel for fear of transmission of tainted information. First Wis. Mortgage Trust v. First Wis. Corp., 571 F.2d 390 (7th Cir. 1978).

45. Some states in adopting DR 1-103(A) changed "shall" to "should"-apparently to weaken the obligation. Others have deleted DR 1-103(A). See Note, The Lawyer's Duty to Report Professional Misconduct, 20 ARIz. L. REV. 509, 511 (1979). 
violation of any other disciplinary rule. ${ }^{46} \mathrm{~A}$ conflict of interest of the type considered by this Comment will presuinably violate either DR 4$101(B)^{47}$ or DR $5-105,48$ at least as interpreted in the light of Canon Nine. 49

There is an argument, then, that the Code requires that any possible conflict of interest be reported to the court in some fashion. Courts have recognized the existence of such an obligation. The Fifth Circuit, for exainple, has held that "[w]hen an attorney discovers a possible ethical violation concerning a matter before a court, he is not only authorized but is in fact obligated to bring the problem to that court's attention." 50 A district court has also asserted that the proper way to bring opposing counsel's conflict of interest to the court's attention is by a motion to disqualify.51 If these two claims are correct, the ethical problein is solved witl the addition of one furtler premise: one is obligated to do what the Code commands.

The first point at which this argument is vulnerable is its interpretation of the Code. It seems clear enough that the Code does assert that there is an obligation to inform the relevant tribunal whenever one knows that there is a conflict of interest. What if one only suspects that there may be a conflict or believes that a conflict will probably develop in the future?

An Informal Opmion of the ABA Committee on Ethics and Professional Responsibility is relevant to this question. The inquiry to the Committee concerned the propriety of inoving to disqualify the firm of an opposing attorney $A$ wlio would probably be required to testify in a contract action. The Committee concluded, "you do have a right, although not necessarily an obligation, to attempt to disqualify the . . .

46. DR 1-102(A)(1) provides: "A lawyer shall not: Violate a Disciplinary Rule."

47. For the text of DR 4-101(B), see note 9 supra.

48. DR 5-105 provides in pertinent part:

Refusing to Accept or Continue Employment if the Interest of Another Client May Impair the Independent Professional Judgment of the Lawyer.

(A) A lawyer shall decline proffered employment if the exercise of his independent professional judgunent in behalf of a client will be or is likely to be adversely affected by the acceptance of the proferred employment, or if it would be likely to involve him in representing differing interests, except to the extent permitted under DR 5-105(C).

(D) If a lawyer is required to decline employment or to withdraw from employment under a Disciplinary Rule, no partner, or associate, or any other lawyer affiliated with hiin or his firm, may accept or continue such employment.

49. See generally Note, supra note 31.

50. In re Gopunan, 531 F.2d 262, 265 (5th Cir. 1976). See also In re Grand Jury, 446 F. Supp. 1132 (N.D. Tex. 1978); Estates Theatres, Inc. v. Columbia Pictures Indus., 345 F. Supp. 93, 98 (S.D.N.Y. 1972).

51. E.F. Hutton \& Co. v. Brown, 305 F. Supp. 371, 376 (S.D. Tex. 1969). 
firm." 52 The Committee prefaced this conclusion with the somewhat puzzling explanation that "[w] $[$ hether or not $A$ and his firm should be disqualified from representing the defendant in the litigation if $A$ testifies is a matter to be decided by the court before whom the case is pending. We, accordingly do not think that the provisions of DR 1-102 and DR 1-103 are applicable."53

It is possible, but unlikely, that the Committee intended to say that there is never a duty to move to disqualify - since whether or not counsel should be disqualified is ultimately "a matter to be decided by the court before whoin the case is pending." 54 More likely, the Committee felt that in the case of a witness-counsel problem, the court will automatically become aware of the conflict at the time it becomes an actual conflict. When a report would at most apprise the court of the conflict sooner, the report may be ethically optional.

In any event, it seems safe to reach the following conclusions from the Code and Informal Opinion No. 1379. First, the Code does recognize a right to move to disqualify opposing counsel when there is a nontrivial possibility of conflict of interest. Second, there is a duty to inform the court im some maimer when one knows that there is a conflict of which the court might not otherwise learn. Third, there is probably a duty to inform the court when one believes that there is or nay develop a conflict about which the court might not otherwise learn.

Having determined that there is sometimes a duty to inform the court of a possible conflict of interest, the question remains whether the filing of a motion to disqualify opposing counsel is the only proper way to convey this information. Surely the answer is in the negative. Channels of communications with the court are not so limited. A conscientious attorney who is eager to move the proceedings along quickly will inform the court of a conflict of interest and waive objection to it. ${ }^{55}$ So, despite some ill-considered judicial language, ${ }^{56}$ such a motion is at most $a$ proper way to inform the court of a conflict of interest, not the proper way.

Thus, while DR 1-103 does not establish a duty to move to disqualify opposing counsel, the Code does recognize such a motion as ethically permissible. Is the Code correct about this? Is there always a

52. INFORMAL OPINIONS, supra note 15 , No. 1379, at 3 (1976).

53. Id.

54. Id.

55. The court can disqualify counsel sua sponte despite the waiver if it views the conflict as sufficiently serious. See Government of India v. Cook Indus., Inc., 422 F. Supp. 1057, 1059-60 n.4 (S.D.N.Y. 1976).

56. E.F. Hutton \& Co. v. Brown, 305 F. Supp. 371, 376 (S.D. Tex. 1969). 
right to move to disqualify when the motion would be nonfrivolous? One thing is clear: the Code would subject no lawyer to discipline for so moving. No Disciplinary Rule would be violated-at least not if the rules are enforced as the Committee on Ethics and Professional Responsibility seens to understand them. That would settle the question for a "legal realist" for whoin " $X$ is ethical" means "no one will be disciplined for doing $X$." This is not, however, the position of the Code, which recognizes ethical ideals, typified by the "Ethical Considerations," as well as the minimuin requirements of the Disciplinary Rules. In some cases motions to disqualify may be permissible under the Disciplinary Rules but impermissible in the inore full-bodied ethics of an ethically sensitive practitioner.

In fact, even if the Disciplinary Rules announced a duty to nove to disqualify in the "hard cases," it nnight, nonetheless, be impermissible to file the motion. It is quite conceivable that the Code is inconsistent with legal ethics at a given point, despite the authoritative bodies that stand behind the Code.57 The drafters of any sort of code will sometimes nnake mistakes. Cases arise that were unforeseen. When the Disciplinary Rules require conduct that seems clearly unethical to inost practitioners, then the Rules simply do not constitute the content of legal ethics on that point. To think otherwise is to take a formalistic approach that is hopelessly renoved from legal ethics as it actually functions within the practice of law. DR 1-103, then, however it may be interpreted, cannot by itself settle the ethical status of motions to disquahify opposing counsel in those cases in which the expected injury from the conflict of interest is small relative to the hardship disqualification will cause the opposing party.

\section{B. Nonrelational Ethics.}

Traditional philosophical theories of ethics contain a fundamental premise that every human being is of equal moral dignity. From this it follows that what is morally permissible (or obligatory) to do to $A$ is morally permissible (or obligatory) to do to $B$, unless there is some morally relevant difference between $A$ and $B$. The basic premise may be illustrated by looking to its consequences for particular normative ethical theories. In the utilitarian calculus for nnaximizing total human happiness, for example, the happiness of any person counts as much as

57. Drafted by the A.B.A. Special Committee on Evaluation of Ethics Standards, the Code and its amendments have been adopted by the House of Delegates of the A.B.A. See CoDE i-ii. It has also been adopted by the legislature or the court system of every state except California. The Code's continuing authority is called into question by the existence of a committee to draft a new Code. 
that of any other person in determining what is morally required. Thus, if the thousand dollars in $A$ 's bank account would produce inore happiness if sent to a starving family in an underdeveloped country, $A$ will be morally obligated to send it off, other things being equal.

At the greatest level of abstraction, a utilitarian would think it morally impermissible to move to disqualify in the ethically "hard" cases. In these cases the harm done the adverse party will, by hypothesis, outweigh the benefit to one's client. It is immaterial from the utilitarian perspective who bears the injuries. The point is to minimize thein. Utilitarians, however, like other traditional inoral theorists, recognize exceptions to the rule that everyone is to be treated in the saine way. There are morally relevant differences ainong people. For example, if $A$ inakes a promise to B but not to $C, A$ will have obligations to $B$ that $A$ does not have to $C .{ }^{58}$

A moral philosophy denying that such relations as parent-child, promisor-promisee, or lawyer-client ever make a moral difference can be called a "nonrelational" ethics. Such an ethics, in its full generality, is extreinely radical, and has probably never been espoused by anyone. ${ }^{59}$ For the purposes of this Comment, all that inust be considered is the possiblity of "nonrelational" legal ethics, in that they deny that the relation between lawyer and client creates an ethical reason for the lawyer to prefer the client's interest to that of the adverse party.

Nonrelational legal ethics, in this sense, provide an easy answer to the "hard cases." One is not permitted to nove to disqualify. This system not only provides an easy and unambiguous answer, but it is an answer with a certain intuitive appeal. After all, one's clients are no better than anyone else-or if they are it is by accident. Why should they be accorded a special place in the noral universe? The answer is that clients do not have a special place in the inoral universe, but they do in the inoral universe of their attorney. They have a special place because the attorney has undertaken to create a special relationship with them. That this relationship makes a difference within legal ethics has systematic as well as intuitive support. Just as the institution of promising could not exist unless promisees were soinetimes treated differently from the rest of humanity, the institution of legal representation could not exist unless chents were sometimes treated differently from nonchents. Legal ethics is not and could not be simultaneously nonrelational and appropriate to any legal system remotely resembling

58. For the utilitarian these obligations arise because the institution of promising is useful. It tends to lead to greater happiness by enabling people to coordmate their affairs.

59. For a philosopliy of legal ethics infiuenced by a form of non-relationalism, see Wasserstrom, Lawyers as Professionals: Some Moral Issues, 5 Human Rights 1 (1975). 
ours. Under strictly nonrelational legal ethics, the lawyer would be under no more duty to write a brief for the client than for the adverse party. For these reasons, strictly nonrelational ethics are implausible, and it would be unwise to turn to them for help in determining the legal ethics of moving to disqualify opposing counsel for conflict of interest.

\section{Strongly Client-Centered Ethics.}

Since nonrelational legal ethics are so clearly wrong, the opposite hypothesis comes to inind: perhaps the lawyer inust favor the client's interest above the interest of all nonclients under all circumstanceshowever small the benefit to the client and however great the harm to the nonclient. The classic statement of the position is Lord Brougham's:

Every one knows that the ties between advocate and chent are of the most sacred nature. It is the duty of an advocate to save his client by all expedient means, to protect him at all hazards, and to the injury of all others, and of himself among those others, if it be necessary. He must not hesitate at the pain he may inflict, or at the destruction he may cause in the prosecution of that duty. ${ }^{60}$

Strongly client-centered ethics provide that a lawful action that benefits the client more than any alternative action is ethically obligatory. Such ethics provide an answer to the "hard questions" of noving to disqualify opposing counsel as easily as do nonrelational ethics. But the answer is, of course, just the opposite. Strongly client-centered ethics require that the motion be made.

Just as there is most probably no one who argues for a nonrelational legal ethics, there may be no one who goes to the limit with a strongly client-centered ethics. ${ }^{61}$ But in the case of client-centered eth-

60. 2 TRIAL of QueEn Caroline 5-6 (1821).

61. DR 7-101 requires client-centered conduct subject to some broad exceptions:

(A) A lawyer shall not intentionally:

(1) Fail to seek the lawful objectives of his client through reasonably available means permitted by law and the Disciphinary Rules, except as provided by $D R$ 7-101(B). A lawyer does not violate this Disciplimary Rule, however, by ... . avoiding offensive tactics ....

(B) In his representation of a client, a lawyer may:

(1) Where permissible, exercise his professional judgment to waive or fail to assert a right or position of his client.

(2) Rcfuse to aid or participate in conduct that he believes to be unlawful, even though there is some support for an argument that the conduct is legal.

The Disciplinary Rules exception of DR 7-101(A)(1) presumably covers frivolous disqualification motions since conduct that would "serve merely to harass or maliciously injur another" is forbidden by DR 7-102(A)(1).

The "avoiding offensive tactics" language of DR 7-10I(A)(1) or, possibly, the "professional judgment" language of DR 7-101(B)(1) arguably except the ethically harder disqualification cases 
ics there are both practitioners and academic theorists who are very close to the full position. ${ }^{62}$ For this reason the position deserves close attention.

1. The Conventional Justification. The justification almost universally given by the proponents of strongly client-centered ethics is that the internal logic of the adversary system requires such ethics. ${ }^{63}$ For this justification of strongly client-centered ethics to succeed, three propositions inust be true: (1) the adversary system promotes important values; (2) those values are not as effectively promoted by any legal ethics other than strongly client-centered ethics; and (3) the values promoted by the adversary system take precedence over all competing values.

The first proposition is easily granted. Historical experience suggests that the adversary system is a good means for promoting justice ${ }^{64}$ and the acceptance of the legal system. It provides a fairly effective way of uncovering factual truth, subject to certam limits, and of ascertaining and developing the law. When functioning properly it provides the parties with the psychological assurance that their interests are taken seriously and are given every chance to prevail, compatible with providing the same chance to the other side. By taking the parties and their cases seriously, the system recognizes and promotes a sense of the fundamental dignity of the person. If there are better means of accomplishing these ends, they remain to be demonstrated.

The second proposition, that strongly client-centered ethics maximize the values of the adversary system, is inore controversial. Strongly client-centered ethics do strengthen the psycliological effects of the systein by encouraging the parties to feel that their interests are being taken seriously. They permit the strongest possible identification of client with lawyer because they place the fewest limits on the lawyer's loyalty to the chent's position. On the otlier hand, a well-known problem is that client-centered ethics pursued to their limits may promote less, not more, truth, ${ }^{65}$ thus inhibiting justice. Strongly chent-cen-

froin the scope of DR 7-101(A)'s obligation exclusively to pursue the client's interests. Moreover, the Code taken in its entirety certainly does not suggest an exclusively client-centered ethics. Strongly client-centered ethics are not simply zealous in pursuing the client's interest. They are lyyperzealous in permitting the pursuit if nothing else. Since this is contrary to the spirit of the Code, its justification must be sought elsewhere.

62. See, e.g., M. Freedman, Lawyer's Ethics In an Adversary System (1975).

63. Id. 2-10.

64. For a general discussion of the justice related values asserted to be associated with the adversary systein, see Golding, On the Adversary System and Justice, in PhilosophiCal Law 98 (R. Bronaugh ed. 1978).

65. Strong attacks on the adversary systein as a truth producer are found in J. FRANK, Courts on Trial (1963) and Frankel, The Search for Truth: An Umpireal View, 123 U. PA. L. 
tered ethics sometimes require the presentation of known perjury, ${ }^{66}$ the nondisclosure of relevant facts or law, and the making of dilatory motions, all practices inimical to the production of truth. Even the appearance of justice may be undermined, for while most clients feel that client-centered ethics on the part of their lawyer produce justice, they are likely to have very different feelings about client-centered conduct on the part of the opposing counsel. ${ }^{67}$ Thus, strongly client-centered ethics increase the behief that the outcome of litigation is controlled by the manipulation of technicalities rather than the merits. It is, therefore, by no means clear that such ethics are maximally effective in pronoting the values that the adversary system is designed to secure.

Harder still to grant is the third proposition, that the values associated with the adversary system take prccedence over all competing values. Justice and the perception of justice in the resolution of legal disputes are surely important, but so are many other values. We would, for example, presumably be unwilling to buy a small increase in justice if the price were a tripling of the size and expense of the legal systein. To take a second example, it is at least not an obvious violation of the values that the adversary system is supposed to promote to inject a nonparty witness with a truth serum. This practice might well be productive of truth, justice, and the assurance that one's case will be taken seriously. Presumably, however, it must nonetheless be ruled out as an impermissible invasion of the person of the witness.

Legal ethics must be congruent with values arismg outside the adversary system. ${ }^{68}$ The adversary system, therefore, does not supply the

REv. 1031 (1975). Criticisms of Frankel's proposals for reform include Freedunan, Judge Frankel's Search for Truth, 123 U. PA. L. REv. 1060 (1975), and Uviller, The Advocate, the Truth, and Judicial Hackles: A Reaction to Judge Frankel's Idea, 123 U. PA. L. Rev. 1067 (1975).

66. M. Freedman, supra note 62, at 27-42. See also Pye, The Role of Counsel in the Suppression of Truth, 1978 DuKE L.J. 921, and authorities collected therein at 924 n.17.

67. This aspect of the problem is obscured when the context of discussion is criminal justice. Hyperzealous prosecution is obviously imcompatible with our crininal justice traditions and values. Thus proponents of strongly client-centered ethics recommend the system only for the defense. See M. FreEdman, supra note 62. One-sided hyperzealous criminal jurisprudence unay be justified by the importance of keeping the innocent from being punished and of counterbalancing the actual and perceived power disparity between the state and the individual. No doubt some sacrifice in trutl and justice is a price worth paying to minimize the punishment of the innocent and to protect the human dignity of the accused; but there is a countervailing consideration in the perception of injustice by the prosecutor's "clients," the public.

68. Just as the fundamental question of philosophical jurisprudence is the relation of the law to morality, so the fundamental question of the jurisprudence of legal ethics is the relation of that etliics to the wider morality.

A legal ethics in radical conflict with the values of general morality would presunably not be a correct legal ethics. Positivism is a less plausible hypothesis with respect to legal ethics than it is with respect to law. But the extent to which general values must infuse legal ethics is far from clear. Not every conflict between the two systens of values is necessarily fatal. The lawyer can 
axioms from which all questions of legal ethics may be deduced. Even if the adversary system would be best promoted by client-centered ethics, the correctness of these ethics could not be inferred.

2. An Alternative Justification. It is not hard to demonstrate the madequacy of the standard argument for client-centered ethics. There is, lowever, a second argument for client-centered ethics that has received little theoretical attention, though it is closely related to the reason many practitioners are client-centered in their ethical practice. The key premise of this second argument is that a correct system of legal ethics must prescribe standards that the legal profession is capable of meeting. That "ought" entails "can" is philosophically uncontroversial. What is controversial is low the "can" is to be analyzed. A correct ethical system obviously will not require what is logically ${ }^{69}$ or pliysically mipossible. ${ }^{70}$ But it is arguable, as well, that a correct ethical system will not impose obligations that people are imcapable of carrying out due to deep-seated psycliological mcapacity. ${ }^{71}$ Many systems of general ethics recognize this limitation by making a distinction between two kinds of good actions. An action that is the best action that could be performed in the situation is obligatory only if it is of a sort that morally trained but ordmary people could be counted on to perform in those circumstances a reasonable percentage of the time. On the other hand, if the best action under the circumstances is of a sort that only saints or moral heroes could be expected to perform, then it is said to be "supererogatory." To perform the action is commendable but not obligatory. ${ }^{72}$ An example of an action widely regarded as supereroga-

always step outside of his or her role as defined by legal ethics in response to "higher" inoral concerns. By not requiring a complete correspondence between legal ethics and general morality, it may be possible to make legal ethics simpler, more systematically unified, and thus easier to learn and employ in common situations.

69. An example of a logically impossible action is the construction of the diagonals of a circle.

70. An example of a pliysically impossible action is jumping across the Mississippi River at St. Louis.

71. A "deep-seated psycliological incapacity" for these purposes is one that could not be overcome by reasonable levels of moral instruction within a period of several years. The causes of such incapacities may lie in genetic structure, but they may also be social in origim, imvolving such matters as the demands of competition and peer pressure.

72. The distmction between what is obligatory or mandatory and what is commendable is made within ethical systems. It is not a distinction dividing law from ethics. While ethical and legal obligations differ, obligation is not foreign to ethics. To claim, as does Dean Patterson, that "ethical rules are only commendatory in nature, whereas legal rules are mandatory," Patterson, $A$ Preliminary Rationalization of the Law of Legal Ethics, 57 N.C.L. REv. 519, 519 (1979), is to confuse being "only commendatory" with the absence of official sanctions. That one may not unurder another is morally as well as legally obligatory. We do not commend one another for not having coinmitted murder yesterday. 
tory is risking one's life to save a stranger.

An ethical system that fails to make this distinction, and makes all best actions obligatory, is probably too difficult for inost people to live up to, as is Utilitarianism if it requires the average American to send most of his or her wealth to underdeveloped countries. Since its prescriptions will be violated, there will be a divergence between ethical theory and practice, which may widen into a disrespect for the ethical system as a whole. This disrespect, in turn, is likely to lead to a general breakdown of the system, including those aspects that people would have followed under other circumstances.

There is a plausible argument, then, that any ethical system that is too rigorous caunot be a correct ethical system. ${ }^{73}$ Ethics is an institution whose purpose is to guide human conduct. Any system incapable of so doing fails the threshold requirement. If this argument is correct, then the set of candidate ethics can be described as "psychologically constrained." What the ethics can demand is limited by what the target population can be expected to follow.

On the other hand, it is not inconceivable that there is a single correct system of general ethics whose truth is quite independent of matters of moral psychology. To suppose that truth is in part a function of our psychological weaknesses does not give the moral law the transcendent status many traditional theorists have ascribed to it. ${ }^{74}$ On these accounts, if we are incapable of living up to the dictates of the moral law, so much the worse for us!

Fortunately, it is not necessary, for the purposes of this Comment, to investigate the question of psychological constraint within the context of general ethical theory. The issue can be restricted to the setting of professional ethics, and within that setting the plausibility of psychologically constrained ethics is especially great. Professional ethics are practical, working ethics. There is nothing to be gained in having professional ethics that are too difficult to be adhered to. The losses are inevitable and obvious: cynicisin, disillusionment, hypocrisy, and ill feeling toward the profession on the part of the rest of the population. These are reasons to believe that professional ethics ought to be psychologically constrained even if general ethics is not. If nembers of society, lawyers and laypersons, were in a position to choose whether legal ethics should be psychologically constrained or not, the desire that the system be effective would presumably dictate that the choice be made in favor of psychological constraint. That society would so

73. See J. RAWLS, A THEORY OF Justice i76-78 (1971).

74. Plato and Kant are representatives of this tradition. 
choose is at least good evidence that a correct legal ethics must be psychologically constramed..$^{75}$

Having concluded that the system must imclude psychological constraints, the next task is to ascertain the breadth of the constraints. At one extreme, it might be suggested that lawyers can, as an einpirical matter, follow no ethics but that of self-interest. That would, however, amount to following no ethics at all. Such a situation would not necessarily mean that law as a profession would deteriorate in the way it relates to the rest of the world. Enlightened long-term self-interest can sometimes produce remarkably civil conduct. But it would, under these circumstances, be better to let the notion of legal ethics fade into history.

It is a plausible hypothesis that in the present state of society lawyers are, for the most part, able to hive up to the demands of a chentcentered ethics, but are generally unable to hive up to an ethics that occasionally requires that the interests of nonclients be preferred to those of chents.

In contrast to an ethics of self-imterest, chient-centered ethics have a distinct content, for client-centered ethics prohibit a good deal of conduct that is at least in the short-run interest of the attorney. This is particularly true in motion practice, where dilatory motions may increase fees without advancing the interest of the chent. Client-centered ethics forbids this practice, and in so doing demonstrates that it is sufficiently distimguishable from simple self-imterest to warrant the naine "ethics."

There are significant advantages that would be derived from the profession's embracing officially and publicly the chent-centered solutions to the hard questions of motions to disqualify opposing counsel. Ethical norms would not be distant from actual practice. Ethical lawyers would be at no competitive disadvantage agamst their less scrupulous fellows. Hypocrisy would be minimized. Of course, this solution requires that the problems of unjustified disqualification and of notions intended to harass the opposing party be dealt with in some way other than by imposing an obligation on the lawyer to consider the interests of the adverse party before moving to disqualify opposing counsel. Statutory or judicial restriction detailing when disqualification can be granted is an obvious means for dealing with the first prob-

75. Just what is shown by thought experiments in which subject populations make rational choices among alternative ethical principles is open to debate. Minimally, the principles that would be chosen have a prima facie claim to being correct-assuming a proper construction of the experiments. For the inost ambitious and well-developed use of this method, see J. RAwLS, supra note 73 . 
lem. If disqualification is restricted to those cases in which it is genumely necessary to insure justice, the problem of questionable disqualification motions would presumably recede without requiring any special ethical self-policing by attorneys. A further advantage would be superior protection for the parties. That such narrowing is already underway is suggested by judicial relaxation of the artificial vicarious disqualification rules and judicial unwillingness to accept strained "appearance of impropriety" reasoning. ${ }^{76} \mathrm{~A}$ judge is in a much better position to watch out for the interest of a party than is opposing counsel.

The problem of harassment and delay by motions that are not expected to succeed could be dealt with by a system of penalties. ${ }^{77}$ Delay could also be prevented by eliminating direct appeals from orders denying disqualification of counsel..$^{78}$

In short, there are ways of dealing with the undesirable effects of client-centered ethics other than modifying the ethics. The public image of a lawyer, willing to inake use of any technical device to the advantage of his or her client, is not such an unattractive one if the profession structures the technical devices available so that their utilization does not produce serious injustice.

\section{Restricted Client-Centered Ethics.}

While client-centered ethics may be structured to provide a passable solution to the problems connected with motions to disqualify opposing counsel, there are alternatives that are inore desirable. Two of these more desirable alternatives will be discussed here. Both represent modifications of the strictly client-centered approach, and both make use of the same general decisionmaking procedure. Under the first alternative, the main step of the procedure is commendable but not obligatory, while under the second alternative the entire procedure is obligatory. Exammation of the differences between the two alternatives and the grounds for preferring one to the other is best postponed until after a discussion of their shared general procedure.

76. See notes $19-40$ supra and accompanying text.

77. DR 7-102(A)(1) arguably already provides a basis for such sanctions. Strictly speaking, the penalties would have to be assessed against the client were they to function within a pure client-centered ethics. However, it is not extravagant cynicisin to believe that penalties assessed against the attorney personally would be an effective deterrent even for fairly consistent chentcentered attorneys. Probably the best way to conceptualize such penalties is to think of them as building a small exception into client-centered ethics. The exception, enforced by direct judicial sanctions against the attorney, runs in favor of the adverse party and prohibits filing a meritlcss motion. The court in one recent case has assessed attorney's fees, expenses, and costs against the moving attorney. See notes $41-42$ supra and accompanying text.

78. Melamed v. ITT Continental Baking Co., 592 F.2d 290, 295 (6tlı Cir. 1979). 
1. The Decision Procedure. There are two threshold matters. First, it is impermissible to move for disqualification when one knows that there is no conflict of interest or only a benign technical conflict. This nuch, thougli potentially incompatible with strongly client-centered ethics, seenis a minimuni requirement of fundamental lionesty and is surely embraced by the lawyer's status as an officer of the court. Second, and for the sanue reasons, if there is a nontrivial possibility that there is a genuine conflict of interest of which the court miglit otherwise be unaware, there is a duty to inform the court, tliough not necessarily by filing a motion to disqualify. ${ }^{79}$ The admonitions of the Code ${ }^{80}$ and the courts to report conflicts of interest reinforce this duty. ${ }^{81}$

With these threshold requirements in mind, we inay address the substance of tlie proposed decision procedure. Whetler there is a duty to inove for disqualification will depend primarily upon a weighing of the advantage to the client in making the motion against the disadvantage to tlie adverse party. ${ }^{82}$ The attorney should not make the motion if the client's advantage in eliminating the adverse party's conflict of interest is very small relative to the adverse party's loss due to factors otlier than the loss of the confiict of interest advantage.

The weighing process should then be fine tuned by taking into account factors that militate against filing the motion. The relevant factors are whether tlie adverse party is deprived of constitutional or other fundainental rights; whether the conflict of interest will appear to the public to be nerely technical; whether the disqualification would cause inefficiencies and dislocations in the provision of legal services by forcing firms to adopt an overly cautious attitude toward potential conflicts of interest; and whetler the behavior of the opposing party in the course of the litigation has been free from techirical nuanipulations and dirty tricks. ${ }^{83}$

79. See text accompanying notes 45-56 supra. Note that this obligation to inform may also run counter to client-centered ethics. Either because of considerations of time or because one believes opposing counsel to be less than the best available, one may not want opposing counsel disqualifled even though there is a genuine conflict of interest. Under such circuinstances it is in the client's interest that information not reach the bench on the basis of which the judge might disqualify opposing counsel sua sponte.

80. DR 1-103. See notes $45-49$ supra and accompanying text.

81. See note 50 supra and accompanying text.

82. See notes 21-23 supra and accompanying text.

83. The bad behavior of opponents is sometimes cited by praetitioners as a reason for ethical coruer cutting. The danger in such arguments is that they encourage a feedback phenoinenon and a steady decline of ethical standards in practice. It is probably neither possible nor desirable to eliminate the intuition that those who exhibit good behavior deserve better than those who do not. The correct solutions would seein to be that all opponents receive a floor level of ethical consideration-however far their own behavior falls below that floor-while those who exhibit standards above the floor be dealt with on at least their own level. 
2. The Procedure as Nonobligatory Ideal. In the first proposed solution to the problem of when to move to disqualify, only the two threshold matters are obligatory. The weighing of imterests, the heart of the procedure, is prescribed as an ideal. The ethically robust practitioner will follow it, but it is not obligatory. In this respect the first solution parallels the Code's distinction between Ethical Considerations and Disciplinary Rules. The threshold principles, like the Disciplinary Rules, are obligatory, and it would be appropriate for them to be enforced through disciplinary action. The use of the weighing procedure, on the other hand, is not appropriately enforceable. It would, however, be recommended and praiseworthy, or, as the Code says of the Ethical Considerations, "aspirational in character . . . [representing] the objectives toward which every member of the profession should strive." 84

This solution is superior to strictly chent-centered ethics in requiring the threshold steps. These steps are essential to a proper operation of the system, even if nearly all the responsibility for avoiding unjustified disquahifications rests with the court. They further the values of the adversary system, and it is unlikely that making them obligatory would be too demanding from the point of view of moral psychology. The second step, reporting a conflict, will only rarely be contrary to the movant's interest, while the first, refraining from moving to disqualify in very weak cases, usually involves, at most, giving up a temporary delay and harassment device whose long-run tactical advantageousness is open to serious doubt. These threshold steps then, while desirable, represent such a small departure from strictly chent-centered ethics that the problem of overrigorousness presumably cannot arise.

The more important stage of the procedure, the weighing of the client's interest against those of the opposing party, is only recommended. This recoininendation is, however, a departure from the strict client-centered system, since it asserts the desirability of looking to other interests im addition to the chent's. In establishing only an ideal, rather than an obligation, however, it avoids the problem of excessive rigorousness. Moral psychology casts doubt on a nonobligatory ideal only when the ideal is so elevated that no one could be expected to live up to it, even im part, im any circumstances. The weighing procedure clearly does not represent such an unapproachable ideal.

For these reasons, the first solution to the issue of moving to disqualify opposing counsel can be expected to work, even given the truth of the key empirical hypothesis supporting the moral psychological ar-

84. CODE Preliminary Statement. 
gument for client-centered ethics-the hypothesis that an obligation to take the nonclient's interest into account would be too demanding for the great majority of lawyers. Moreover, the solution is more attractive than the strictly client-centered theory im permitting interests other than the client's to be taken into account when they are especially pressing. There seems to be no reason, then, not to prefer this solution to that offered by strictly client-centered ethics.

It is possible, however, that the empirical hypothesis that supports the moral psychological argument for client-centered ethics is false, and that a significant proportion of lawyers are capable of taking the interests of the adverse party and opposing counsel into account in deciding whether to move to disqualify opposing counsel. If this is true, a second solution is to be preferred over the one just discussed-a solution that departs a little further from strictly client-centered ethics.

3. The Procedure as Obligatory. To make the weighing procedure itself obligatory, as well as the threshold steps, is to require utilization of both the initial balancing and the secondary fine-tuning procedure. To make this procedure obligatory is to assert not only that it is a good thing to take nonclient interests imto account, but that not to do so is an ethical failing for which censure is appropriate. Disciplinary measures stronger than informal private censure could be applied, though they need not be.

This solution is superior to its less demanding brother if the key einpirical hypothesis is false, and a significant number of lawyers are able to depart from client-centered behavior by engaging in the weighing procedure. It is likely that lawyers are capable of rising above client-centered behavior to this degree, since the weighing procedure is not itself a very dramatic departure froin client-centered conduct. It does not call for an equal weighing of the interests of client and nonclient. Rather, it prefers the imterest of the client unless the interest of the nonclient is disproprotionately greater, as, for example, when the adverse party's interest is a matter of constitutional or other fundamental rights, and the client's is not.

There are two reasons for the narrowness of the departure from the client-centered system. First, while the "adversary-systenn argument" for client-centered ethics is unsuccessful, ${ }^{85}$ it is not wholly inisguided. The adversary system does protect important values, and there is a close relationship between the adversary system and those ethics that inake the interests of the client central. Too great a departure from

85. See text accompanying notes 63-68 supra. 
client-centeredness would be incompatible with the efficient functioning of that system, and even if replacements of equal or greater value are possible, they are unlikely to be arrived at short of a careful and exhaustive rethinking of the entire system of justice. To render the adversary system less adversary in small ways when it collides with other important values is not to scrap it altogether. To make it less adversary in larger ways might well be.

Second, even if the major hypothesis of the moral psychology argument is false, and a sigmificant number of lawyers would not find it too demanding to give nonchicnt interests priority under certain circumstances, still, experience suggests that the hypothesis is not too far off base. Overextension of the circumstances under which the attorney must give priority to the interests of nonclients would thus render the ethical demands too rigorous for the overwhelming majority of practitioners, and the ethics would cease to guide conduct effectively. While the proposed solution does not depart too far from client-centered ethics, recommendations of the two systems will solnetimes diverge. Under the system proposed here, for example, the lawyer might be required to refuse his or her chent's request to disqualify opposing counsel.

It is worth pausing to consider how the attorney would justify this refusal to the client. No doubt it would help a great deal if the attorney could poimt to a requirement in a code of legal ethics. If the provision were backed by disciplinary sanctions, that might satisfy the client. The client, however, might well wonder how the code provision itself is to be justified. So, to isolate the real justification problem, let us imagine an attorney who seeks to justify refusing a chent's request in the absence of a disciplinary rule.

The lawyer might first cite the disproportionate imjury to the adverse party. This is, $\mathrm{m}$ fact, the heart of the matter, ethically speaking. The lawyer, however, may anticipate that some clients, having little charity in their hearts for the opposing party, will be quite unmoved by this consideration. An argument in terms of the institutional effects of the ethical requirement will probably be more persuasive. The attorney could explaim that the proliferation of disqualification motions tends to produce delay and to tie up legal resources, thus increasing the expense while perhaps lowering the quality of legal services. Such dislocations in the legal systein obviously run counter to the long-run interest of clients-including the present client.

The astute client might conclude that client-centered ethics justifies the refusal to move to disqualify after all. The purported novelty of the "restricted client-centered" proposal is inerely that it emphasizes 
the client's long-run interest as a consumer of legal services rather than his or her short-run interest with respect to the present litigation. Having reached this conclusion, the client might well demand to be the arbiter of the decision as to liow his or her slort-term and long-term interests are to be balanced. Client-centered ethics provide no justification for a refusal to allow the client to make a decision when the client is willing to shoulder the responsibilty for the possiblity that, in the long run, the decision is a mistake.

Having been driven into the corner by a client who understands these issues, the lawyer will have to admit that the refusal to move to disqualify is ultimately justified by the short- and long-term interests of persons otler than the client. That the refusal is probably also in the long-run interest of the client is a bonus that may or may not inollify the client and minimize the psychic dissonance of the attorney.

\section{CONCLUSION}

While changing judicial attitudes toward disqualification of counsel $^{186}$ can be expected to result in fewer wholly unjustifiable disqualifications, there will remain cases in which such disqualifications will take place, and more numerous cases in which delay and expense will result from the necessity of disposing of inotions that should not have been made. The responsibility for avoiding these abuses rests squarely on the potentially inoving counsel.

The ethical principles that should be relied upon in deciding whether or not to move to disqualify opposing counsel represent a modest departure from strictly client-centered ethics. It is desirable that the departure be modest because legal ethics, as working ethics, are properly constrained by those aspects of the social psycliology of lawyers that are unchangeable in the short and medium run.

The first and easiest departures are that lawyers must not make frivolous notions and that they must inform the court of possible conflicts. While it would arguably be in the client's interest to ignore these rules, compliance will rarely run seriously counter to the client's interests.

The remaining questions as to when it is ethically obligatory, permissible, and impermissible to inove to disqualify opposing counsel for conflict of interest will depend upon just how deinanding a set of obligations lawyers can be expected to follow. If a statistically significant number of lawyers could not follow obligations more deinanding than those of client-centered ethics, then it will be permissible to move to

86. See notes $19-42$ supra and accompanying text. 
disqualify opposing counsel in the "hard cases"-those cases in which the elinination of the conflict is a minor matter relative to the losses inposed upon the adverse party by the loss of counsel. Even under this hypothesis, however, it would not be obligatory to move to disqualify opposing counsel in these cases. Professional ethics can have ideals of conduct even if only a sinall number of practitioners could hive up to them on a regular basis. The preferred conduct, and the course that legal ethics should recominend is a weighing procedure that requires some attention to the interests of the adverse party. This decision procedure is superior to that of client-centered ethics because it gives proper scope to other values at the point that they take precedence over the value of attorney loyalty to chent.

If a statistically significant group of lawyers could follow obhigations significantly more demanding than those of client-centered ethics, then the weighing procedure slould be an ethical obhgation rather than an ethical ideal. It would be ethically impermissible to move to disqualify if the loss to the adverse party would be disproportionate, or mvolve fundainental values. In borderline cases the attorney should consider the prior conduct of the adverse party, the way the motion would appear to the public, and whether it would adversely affect the efficient provision of legal services.

Lawrence Crockert

$\dagger$ Associate Professor of Philosophy, University of Washington (on leave). 